\title{
Effect on growth Performance of Clarias gariepinus Juveniles Fed Fermented Mango Seed Kernel Diet at Different Inclusion Level
}

\author{
Augustine Eyiwunmi FALAYE ${ }^{1} \mathbb{D}$, Shakiru Okanlawon SULE ${ }^{2 *}$, Mamady KOUROUMA ${ }^{3}$ (D) \\ ${ }^{1}$ Department of Aquaculture and Fisheries Management University of Ibadan, Ibadan, Nigeria. \\ ${ }^{2 *}$ Department of Forestry, Wildlife, and Fisheries, Olabisi Onabanjo University, Ayetoro Campus, Ogun State, \\ Nigeria. \\ ${ }^{3 .}$ National Agency for Aquaculture, Ministry of Aquaculture and Fisheries Economic Maritime, Guinea.
}

*Corresponding Author: okanlawon.sule@yahoo.com sule.okanlawon@ oouagoiwoye.edu.ng

Received 11 September 2020; Accepted 01 March 2021; Release date 01 June 2021.

How to Cite: Falaye, A. E., Sule, S.O \& Kourouma, M. (2021). Effect on growth performance of Clarias gariepinus juveniles fed fermented mango seed Kernel Diet at different inclusion level. Acta Aquatica Turcica, 17(2), 214-220. https://doi.org/10.22392/actaquatr.793887

\begin{abstract}
The main objective of this research was in the utilization of agro-wastes from fruit processing and consumption. This waste has resulted to environmental nuisance and the need for incorporation into aquaculture feed as energy source is inevitable. The utilization of waste from fruit processing can be used to reduce the cost of feed production. This research utilized fermented Mango Seed Kernel Meal (MSKM) as a replacement for maize in the diets of Clarias gariepinus juveniles. A $40 \%$ isonitrogenous diet was formulated ât inclusion levels of $\mathrm{T}_{1}(0 \%), \mathrm{T}_{2}(25 \%), \mathrm{T}_{3}(50 \%), \mathrm{T}_{4}(75 \%)$, and $\mathrm{T}_{5}$ (100\%) MSKM and fed at 3\% body weight. One hundred and fifty (150) Clarias geriepinus juveniles average, the weight of $10.00 \mathrm{~g} \pm 0.14$ were randomly allocated to Treatments in plastic tanks $(49 \times 33.5 \times 33.5 \mathrm{~cm})$ at 10 fish per treatment/tank in triplicate. Mean Weight Gain (MWG) was highest in T1 $(756.37 \pm 13.61 \mathrm{~g})$ and significantly differs $(\mathrm{P}<0.05)$ from other treatments. Feed Conversion Ratio (FCR) was highest in T4 $(1.46 \pm 0.18 \mathrm{~g})$ and lowest in T1 $(0.99 \pm 0.01 \mathrm{~g})$. Specific Growth Rate (SGR) was significantly different in T4 when compared to other treatments. Feed intake and feed cost decreased with the inclusion level of MSKM while net profit was not significantly different $(\mathrm{P}>0.05)$ in $\mathrm{T} 1$ and T3. Profit index and net profit were significantly compared in T2, T3, and T5. The diet showed no implication on fish survival. In conclusion, the growth performance of Catfish could be improved by substituting MSKM at 50\% level without implication on cultured fish.
\end{abstract}

Keywords: Agro-waste, Catfish, Feedstuff, Mangifera indica,

Clarias gariepinus Balıklarının Yemlerine Farklı Düzeylerde Fermente Mango Çekirdeği ile Beslemenin Yavruların Büyüme Performansına Etkisi

$\mathrm{Bu}$ araştırmanın amacı, meyve işleme ve tüketiminden kaynaklanan tarımsal atıkların değerlendirilmesidir. Bu atıklar çevresel rahatsızlıklara yol açmaktadır ve bu ürünlerin su ürünleri yemlerine enerji kaynağı olarak katılması düşünülmüştür. Meyve işlemeden kaynaklanan atıkların kullanımı üç tekerrürlü olarak tanklarda yürütülmüştür. Ortalama Ağırlık Kazancı (MWG) en yüksek T1 $(756.37 \pm 13.61 \mathrm{~g})$ grubunda tespit edilmiş ve diğer gruplarla önemli derecede farklı bulunmuştur (P $<0.05)$. Yem Dönüşüm Oranı (FCR) en yüksek T4 $(1.46 \pm 0.18 \mathrm{~g})$ ve en düşük T1 $(0.99 \pm 0.01 \mathrm{~g})$ grubundan elde edilmiştir.

Spesifik Büyüme oranı (SGR) T4 grubunda diğer gruplara göre önemli ölçüde farklı bulunmuştur. Yem alımı ve yem maliyeti, MSKM'nin dahil edilme seviyesi ile azalırken, net kar T1 ve T3 grubunda benzerdi(P>0.05). Deneme yemleri, balıkların hayatta kalması üzerinde hiçbir etki göstermedi. Sonuç olarak, yayın balıklar üzerinde herhangi bir etki yapmadan MSKM'nin\% 50 seviyesinde ikame edilmesi büyüme performansını iyileştirilebilir.

Anahtar Kelimeler: Tarımsal atık, Yayın balığı, Yem hammaddesi, Mangifera indica

\section{INTRODUCTION}

Utilizing cheaper alternative energy feedstuffs can reduce fish feed cost which is of paramount importance and imperative. Carbohydrates feedstuffs abound in nature and are important in animal feeds formulation to meet their nutritional requirement for growth and physiological processes of life. Carbohydrates are the major source of dietary energy for terrestrial animals; however, the ability of fish to utilize carbohydrates varies among fish species (NRC, 1993). Maize is a cereal crop consumed by man and livestock. The increasing prohibitive cost of maize due to human and livestock competition has necessitated the need to search for an alternative source of energy in livestock 
nutrition. Hence the need to explore cheaper energy sources to replace expensive cereals in fish feed formulation (Falaye, 1992). Researches have documented the utilization of plant sources and agricultural wastes such as plantain peel meal (Falaye and Oluruntuyi, 1998); cassava leaves (Bichi and Ahmadu, 2010); maize brans (Falaye, 1998); cocoa pod husk (Falaye and Jauncey, 1999); MSKM and palm kernel meal (Omoregie, 2001); mango peel meal (Omojowo et al., 2010) and star apple (Jimoh et al., 2013) in aquaculture as an energy source which had relieved the food feed competition between man and animal and profit maximization in production operations.

Falaye (1992) reported that large quantities of these crop residues and agro-industrial wastes that can be utilized as diet components are wasted annually. The ready availability and digestibility of maize made it a choice in human and livestock nutrition. The rising cost of maize and its accompanying scarcity is making it increasingly uneconomical to utilize it for livestock including fish (Sotolu and Byanyiko, 2010). The abundance of MSKM could serve as an alternative energy source, therefore, contribute huge benefit for the sustainability of the aquaculture industry, if harnessed. Research is lacking on the use of MSKM in the catfish diet. Hence this study evaluated the growth response of Clarias gariepinus juvenile fed fermented MSKM at varying inclusion levels in replacement for maize.

\section{MATERIAL AND METHODS}

\section{Experimental design and trial experiment}

Mango Seed was collected from the local market in the Ibadan metropolis and the kernel of the samples obtained by cutting the seed coat using a kitchen knife. The Mango Seed Kernel (MSK) obtained was fermented for 72 hours at $100 \mathrm{~g} / \mathrm{L}$ of water in a container for 3 days with water exchange at 8 hours intervals and sundried. A $40 \%$ crude protein experimental diet was prepared at different inclusion levels of MSKM $(0,25,50,75$, and 100\%) (Table 2).

The feeding trial was conducted in Laboratory C, Department of Aquaculture and Fisheries Management; University of Ibadan, for 12 weeks duration. Clarias gariepinus juveniles were obtained from a reputable fish farm were acclimated for two weeks in the rectangular plastic tank of 35 liters $(49 \times 33.5 \times 33.5 \mathrm{~cm})$. A total of One Hundred and Fifty (150) C. gariepinus juveniles $(10.00 \pm 0.14 \mathrm{~g})$ were allotted randomly in replicate at ten fish per treatment $\left(T_{1}, T_{2}, T_{3}, T_{4}\right.$, and $\left.T_{5}\right)$ in a complete randomized design.

Fish were fed at $3 \%$ body weight daily. The weight of each experimental tank fish was taken biweekly using an electronic weighing scale. The water quality parameters were measured and recorded biweekly, between 8:00-10:00 am using API ${ }^{\circledR}$ Freshwater Master Test Kit. The proximate composition of experimental diets and fish carcass were analyzed according to AOAC (2005). Metabolizable energy value was calculated according to Pauzenga (1985). Amino Acid profile of feed was determined as described by Benitez (1989) using Applied Biosystems PTH Amino Acid Analyzer. Mineral analysis of feed was by the use of Nitric acid and perchloric acid for $\mathrm{Ca}, \mathrm{Mg}, \mathrm{Mn}, \mathrm{Fe}, \mathrm{Cu}$, and Zinc. $\mathrm{K}$ and $\mathrm{Na}$ and $\mathrm{P}$ were determined by molybdo-vanado method using the Atomic Absorption Spectrophotomer.

Table 1: Nutritional composition of Fermented Mango Seed Kernel Meal and Maize.

\begin{tabular}{lll}
\hline \hline & MSKM & Maize \\
\hline Crude protein \% & 5.95 & 9.00 \\
Ether extract \% & 14.90 & 5.40 \\
Crude fibre \% & 9.80 & 2.96 \\
Ash \% & 1.10 & 2.10 \\
Moisture content \% & 35.46 & 12.00 \\
Nitrogen Free Extract (NFE) & 32.79 & 68.54 \\
Energy (Kcal/kg) & 2586.62 & 3176.62 \\
\hline \hline Energy calculation: $\left(37 * \%\right.$ Crude protein) $+(81.8 * \%$ ether extract $)+\left(35^{*} \% \mathrm{NFE}\right)$
\end{tabular}


Table 2: Diet composition and nutritional profile of experimental diet.

\begin{tabular}{|c|c|c|c|c|c|}
\hline & Treatment 1 & Treatment 2 & Treatment 3 & Treatment 4 & Treatment 5 \\
\hline Maize & 26.55 & 19.90 & 13.28 & 6.65 & 0 \\
\hline Mango seed meal & 0 & 6.65 & 13.28 & 19.9 & 26.55 \\
\hline Soybean meal & 23.53 & 23.53 & 23.53 & 23.53 & 23.53 \\
\hline Groundnut cake meal & 23.53 & 23.53 & 23.53 & 23.53 & 23.53 \\
\hline Fish meal & 23.53 & 23.53 & 23.53 & 23.53 & 23.53 \\
\hline Bone meal & 1.00 & 1.00 & 1.00 & 1.00 & 1.00 \\
\hline Oyster Shell & 0.50 & 0.50 & 0.50 & 0.50 & 0.50 \\
\hline Salt & 0.25 & 0.25 & 0.25 & 0.25 & 0.25 \\
\hline Premix & 0.60 & 0.60 & 0.60 & 0.60 & 0.60 \\
\hline Methionine & 0.25 & 0.25 & 0.25 & 0.25 & 0.25 \\
\hline lysine & 0.25 & 0.25 & 0.25 & 0.25 & 0.25 \\
\hline \multicolumn{6}{|l|}{ Chemical analysis } \\
\hline Moisture Content (\%) & $1.90^{\mathrm{a}}$ & $1.68^{\mathrm{c}}$ & $0.97^{\mathrm{e}}$ & $1.20^{\mathrm{d}}$ & $1.79^{\mathrm{b}}$ \\
\hline Crude Protein $(\%)$ & $39.88^{\mathrm{a}}$ & $39.34^{\mathrm{a}}$ & $39.10^{\mathrm{a}}$ & $39.53^{\mathrm{a}}$ & $39.21^{\mathrm{a}}$ \\
\hline Crude Fat $(\%)$ & $4.12^{\mathrm{d}}$ & $4.02^{\mathrm{e}}$ & $4.79^{\mathrm{b}}$ & $4.98^{\mathrm{a}}$ & $4.72^{\mathrm{c}}$ \\
\hline Crude Fibre (\%) & $5.77^{\mathrm{c}}$ & $5.02^{\mathrm{d}}$ & $6.60^{\mathrm{b}}$ & $6.80^{\mathrm{a}}$ & $5.79^{c}$ \\
\hline Ash Content (\%) & $30.89^{c}$ & $31.19^{\mathrm{b}}$ & $29.81^{\mathrm{d}}$ & $32.21^{\mathrm{a}}$ & $29.51^{\mathrm{e}}$ \\
\hline N.F.E $(\%)$ & $17.44^{\mathrm{b}}$ & $18.75^{\mathrm{a}}$ & $18.72^{\mathrm{a}}$ & $15.28^{\mathrm{c}}$ & $18.98^{\mathrm{a}}$ \\
\hline Energy (kcal) & $2422.74^{\mathrm{c}}$ & $2440.67^{\mathrm{b}}$ & $2493.69^{\mathrm{a}}$ & $2404.89^{\mathrm{d}}$ & $2501.17^{\mathrm{a}}$ \\
\hline \multicolumn{6}{|l|}{ Amino acid analysis } \\
\hline Leucine $(\mathrm{g} / 100 \mathrm{~g})$ & 7.18 & 6.48 & 6.07 & 6.94 & 6.89 \\
\hline Lysine (g/100g) & 4.29 & 3.42 & 3.18 & 3.92 & 4.11 \\
\hline Isoleucine $(\mathrm{g} / 100 \mathrm{~g})$ & 3.66 & 3.14 & 2.94 & 3.30 & 3.44 \\
\hline Phenylalanine $(\mathrm{g} / 100 \mathrm{~g})$ & 4.25 & 3.37 & 3.19 & 3.72 & 4.08 \\
\hline Tryptophan $(\mathrm{g} / 100 \mathrm{~g})$ & 0.97 & 0.81 & 0.70 & 0.86 & 0.92 \\
\hline Valine $(g / 100 g)$ & 3.59 & 3.05 & 3.10 & 3.15 & 3.39 \\
\hline Methionine $(\mathrm{g} / 100 \mathrm{~g})$ & 2.27 & 2.08 & 2.00 & 2.13 & 2.24 \\
\hline Proline $(\mathrm{g} / 100 \mathrm{~g})$ & 3.35 & 2.84 & 2.64 & 3.14 & 3.04 \\
\hline Arginine (g/100g) & 6.36 & 4.64 & 4.47 & 4.98 & 5.16 \\
\hline Tyrosine (g/100g) & 3.95 & 3.09 & 2.92 & 3.26 & 3.09 \\
\hline Histidine $(\mathrm{g} / 100 \mathrm{~g})$ & 2.23 & 2.11 & 1.98 & 2.01 & 2.17 \\
\hline Cystine (g/100g) & 1.09 & 0.84 & 0.84 & 0.90 & 0.97 \\
\hline Alanine (g/100g) & 4.36 & 3.56 & 3.71 & 3.94 & 4.02 \\
\hline Glutamic acid $(\mathrm{g} / 100 \mathrm{~g})$ & 9.61 & 8.78 & 7.87 & 9.98 & 9.08 \\
\hline Glycine $(\mathrm{g} / 100 \mathrm{~g})$ & 3.51 & 2.90 & 2.54 & 3.11 & 3.37 \\
\hline Threonine $(\mathrm{g} / 100 \mathrm{~g})$ & 3.11 & 2.94 & 3.16 & 2.99 & 2.94 \\
\hline Serine $(g / 100 g)$ & 3.46 & 3.00 & 2.89 & 3.45 & 3.29 \\
\hline Aspartic acid (g/100g) & 7.41 & 6.54 & 6.14 & 6.88 & 6.94 \\
\hline \multicolumn{6}{|l|}{ Mineral analysis } \\
\hline $\mathrm{Ca}(\%)$ & 8.325 & 7.975 & 8.588 & 8.363 & 8.963 \\
\hline $\operatorname{Mg}(\%)$ & 0.202 & 0.238 & 0.261 & 0.263 & 0.286 \\
\hline $\mathrm{K}(\%)$ & 1.025 & 0.925 & 0.850 & 0.928 & 0.900 \\
\hline $\mathrm{Na}(\%)$ & 0.800 & 0.701 & 0.750 & 0.725 & 0.775 \\
\hline $\mathrm{Mn}(\mathrm{mg} / \mathrm{kg})$ & 149.00 & 124.50 & 173.50 & 127.50 & 141.50 \\
\hline $\mathrm{Fe}(\mathrm{mg} / \mathrm{kg})$ & 537.00 & 660.00 & 515.00 & 535.00 & 700.00 \\
\hline $\mathrm{Cu}(\mathrm{mg} / \mathrm{kg})$ & 5.50 & 10.35 & 10.25 & 10.85 & 11.45 \\
\hline $\mathrm{Zn}(\mathrm{mg} / \mathrm{kg})$ & 62.45 & 11.65 & 44.20 & 41.15 & 47.90 \\
\hline $\mathrm{P}(\%)$ & 1.073 & 1.053 & 1.081 & 1.119 & 1.094 \\
\hline
\end{tabular}

Ca: calcium; Mg: magnesium; K: potassium; Na: sodium; Mn: manganese; Fe: iron; Cu: copper; Zn: zinc; P: phosphorus 
Statistical Analysis: Data resulting from the experiment was subjected to a one-way analysis of variance (ANOVA). Duncan's multiple range test was used to test for differences among means $(\mathrm{P}=0.05)$ using IBM SPSS version 20.

\section{RESULTS}

The proximal analysis of fermented MSKM indicated lower crude protein, ash, NFE, and energy to maize (Table 1). The result of the proximate composition of the experimental diets (Table 2) showed percentage crude protein with no significant difference $(\mathrm{P}>0.05)$. Crude fiber, fat, moisture content, ash content, and carbohydrate parameters measured for the feed proximate composition were significantly different for all treatments. Amino acid analysis of the experimental diets showed $\mathrm{T} 1 \mathrm{had}$ values greater than other dietary treatments. The elemental mineral content of experimental diets showed variations in ranges of content.

The growth response of fish fed varying levels of mango seed kernel meal showed MWG T1 was significantly different $(\mathrm{P}<0.05)$ from other dietary treatments (Table 3$)$. FCR in T4 was significantly different from control and other treatments. SGR in T2, T4, and T5 was significantly different from control and T1. Feed intake and cost of feed were reduced at T5 and significantly different from other treatments.

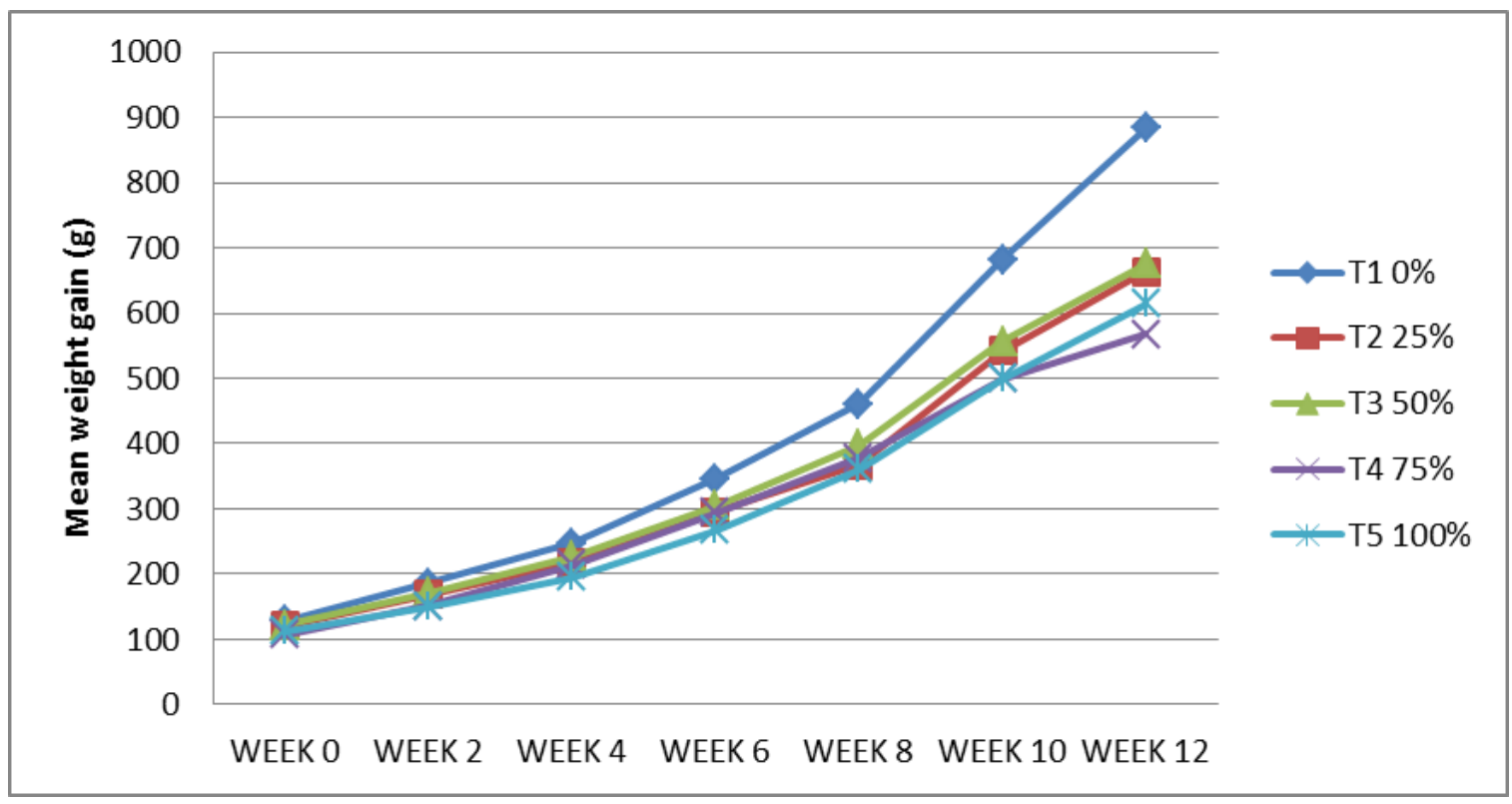

Figure 1: Biweekly Weight Gain (g) of Experimental Fish fed MSKM.

Table 3: Growth Performance of C. gariepinus Fed Varying Levels of MSKM diets

\begin{tabular}{|c|c|c|c|c|c|}
\hline Parameters & Treatment 1 & Treatment 2 & Treatment 3 & Treatment 4 & Treatment 5 \\
\hline Initialweight $(\mathrm{g})$ & $108.67 \pm 1.45^{\mathrm{a}}$ & $107.33 \pm 0.33^{\mathrm{a}}$ & $107.00 \pm 1.53^{\mathrm{a}}$ & $108.33 \pm 1.76^{\mathrm{a}}$ & $109.00 \pm 0.58^{\mathrm{a}}$ \\
\hline Final weight $(\mathrm{g})$ & $865.03 \pm 13.84^{\mathrm{a}}$ & $617.17 \pm 59.31^{\mathrm{b}}$ & $661.83 \pm 24.27^{\mathrm{b}}$ & $567.60 \pm 87.71^{\mathrm{b}}$ & $577.27 \pm 39.31^{\mathrm{b}}$ \\
\hline MWG (g) & $756.37 \pm 13.61^{\mathrm{a}}$ & $509.84 \pm 59.44^{\mathrm{b}}$ & $554.83 \pm 24.38^{\mathrm{ab}}$ & $459.27 \pm 88.71^{\mathrm{b}}$ & $468.27 \pm 39.75^{\mathrm{b}}$ \\
\hline PWG (g) & $696.26 \pm 14.95^{\mathrm{a}}$ & $475.13 \pm 56.06^{\mathrm{ab}}$ & $518.81 \pm 24.99^{\mathrm{ab}}$ & $425.69 \pm 84.79^{b}$ & $429.92 \pm 38.43^{b}$ \\
\hline FCR & $0.99 \pm 0.01^{\mathrm{a}}$ & $1.26 \pm 0.06^{\mathrm{ab}}$ & $1.19 \pm 0.06 \mathrm{~b}^{\mathrm{ab}}$ & $1.46 \pm 0.18^{\mathrm{b}}$ & $1.31 \pm 0.08^{\mathrm{ab}}$ \\
\hline SGR (\%/g/day) & $1.07 \pm 0.01^{\mathrm{a}}$ & $0.90 \pm 0.05^{\mathrm{b}}$ & $0.94 \pm 0.02^{\mathrm{ab}}$ & $0.84 \pm 0.09^{\mathrm{b}}$ & $0.86 \pm 0.03^{\mathrm{b}}$ \\
\hline PI (g) & $301.29 \pm 9.18^{\mathrm{a}}$ & $250.67 \pm 18.74^{\mathrm{ab}}$ & $258.56 \pm 11.85^{\mathrm{ab}}$ & $253.81 \pm 23.08^{\mathrm{ab}}$ & $238.80 \pm 12.61^{\mathrm{b}}$ \\
\hline PER & $0.87 \pm 0.00^{\mathrm{a}}$ & $0.82 \pm 0.01^{\mathrm{ab}}$ & $0.84 \pm 0.01^{\mathrm{ab}}$ & $0.80 \pm 0.04^{\mathrm{b}}$ & $0.81 \pm 0.01^{\mathrm{ab}}$ \\
\hline $\mathrm{NM}(\%)$ & $224.52 \pm 3.28^{\mathrm{a}}$ & $167.06 \pm 13.65^{\mathrm{b}}$ & $177.28 \pm 5.59^{\mathrm{ab}}$ & $155.86 \pm 19.99^{b}$ & $158.24 \pm 896.42^{b}$ \\
\hline Survival Rate \% & $83.33 \pm 6.67^{\mathrm{a}}$ & $90.00 \pm 0.00^{\mathrm{a}}$ & $83.33 \pm 3.33^{\mathrm{a}}$ & $83.33 \pm 3.33^{\mathrm{a}}$ & $93.33 \pm 6.67^{\mathrm{a}}$ \\
\hline Feed Intake & $755.57 \pm 23.20^{\mathrm{a}}$ & $637.00 \pm 46.45^{\mathrm{a}}$ & $661.13 \pm 28.73^{\mathrm{a}}$ & $642.34 \pm 59.52^{\mathrm{a}}$ & $609.19 \pm 33.69^{\mathrm{b}}$ \\
\hline Cost feed & $275.78 \pm 8.47^{\mathrm{a}}$ & $224.86 \pm 16.40^{\mathrm{ab}}$ & $230.73 \pm 10.03^{\mathrm{ab}}$ & $222.25 \pm 20.59^{\mathrm{ab}}$ & $208.34 \pm 11.52^{\mathrm{b}}$ \\
\hline Value of fish & $605.52 \pm 9.69^{a}$ & $432.02 \pm 41.52^{b}$ & $463.28 \pm 16.99^{\mathrm{ab}}$ & $397.32 \pm 61.40^{\mathrm{b}}$ & $404.09 \pm 27.52^{\mathrm{b}}$ \\
\hline Profit index & $3.14 \pm 0.05^{\mathrm{a}}$ & $2.74 \pm 0.10^{\mathrm{ab}}$ & $2.88 \pm 0.14^{\mathrm{ab}}$ & $2.52 \pm 0.17^{\mathrm{b}}$ & $2.77 \pm 0.15^{\mathrm{ab}}$ \\
\hline Incidence cost & $0.32 \pm 0.00^{\mathrm{a}}$ & $0.37 \pm 0.01^{\mathrm{ab}}$ & $0.35 \pm 0.02^{\mathrm{ab}}$ & $0.40 \pm 0.03^{b}$ & $0.36 \pm 0.02^{\mathrm{ab}}$ \\
\hline Net profit & $329.74 \pm 1.22^{\mathrm{a}}$ & $207.15 \pm 26.87^{b}$ & $232.55 \pm 17.25^{\mathrm{ab}}$ & $175.07 \pm 41.03^{\mathrm{b}}$ & $195.74 \pm 22.42^{\mathrm{b}}$ \\
\hline
\end{tabular}


The growth performance parameters were calculated accordingly:

Mean Weight gain $(\mathrm{MWG})=$ Final weight - Initial weight .

Specific Growth Rate $(S G R)=\left(\log _{\text {e final weight }}-\log _{\text {e initial weight }} /\right.$ Time $) \times 100$.

Feed Conversion Ratio (FCR) $=$ Feed fed $(\mathrm{g}) /$ Fish weight gain .

Protein intake $(\mathrm{PI})=$ Feed intake $\mathrm{x} \%$ of protein in the diet.

Protein efficiency ratio $(\mathrm{PER})=$ Mean weight gain $(\mathrm{g}) /$ Protein consumed .

Percentage weight gain $(\mathrm{PWG})=($ Mean weight gain $(\mathrm{g}) /$ Mean initial weight $(\mathrm{g}) \times 100$.

Protein Productive value $(\mathrm{PPV})=$ increment in body protein of fish / protein intake.

Net metabolism $(\mathrm{NM})=0.549 *(\mathrm{w} 1+\mathrm{w} 2) * \mathrm{~T} / 2$.

Survival rate $\%=($ Initial fish stocked - mortality $) /$ Initial fish stocked $* 100$.

Feed intake $=$ Daily feed intake $\times 84$ days.

Value of fish $=$ Final weight $x$ Market Price of fish $(\$ 0.7 / \mathrm{kg})$.

Cost of feed $=$ Feed intake $x$ value of feed $(\mathrm{N} / \mathrm{kg})$. (Note: Value of feed $(\mathrm{N} / \mathrm{kg})$ at $\mathrm{T} 1=\mathrm{N} 0.365$, $\mathrm{T} 2=\$ 0.353, \mathrm{~T} 3=00.349, \mathrm{~T} 4=\$ 0.346, \mathrm{~T} 5=\$ 0.342)$.

Profit index = Value of fish produced $(\mathrm{N} / \mathrm{kg}) /$ Cost of feed used in production $(\mathrm{N} / \mathrm{kg})$.

Incidence cost $=$ Cost of feed used $(\mathrm{N} / \mathrm{kg}) /$ Total weight of fish produced $(\mathrm{kg})$.

Net profit $=$ Total cost of fish cropped - Total expenditure .

Carcass analysis showed a significant difference among all parameters and significantly different from the initial fish carcass (Table 3). Crude protein and ash content were least in control fish but higher than an initial fish carcass.

Table 4: Carcass Composition of initial and final fish fed Experimental Diets.

\begin{tabular}{llllllc}
\hline \hline Parameters & Initial & \multicolumn{1}{c}{ T1 } & T2 & T3 & T4 & T5 \\
\hline Moisture Content (\%) & $19.93 \pm 0.01^{\mathrm{a}}$ & $4.12 \pm 0.01^{\mathrm{d}}$ & $4.11 \pm 0.01^{\mathrm{d}}$ & $4.05 \pm 0.01^{\mathrm{e}}$ & $5.00 \pm 0.01^{\mathrm{b}}$ & $4.51 \pm 0.01^{\mathrm{c}}$ \\
Crude Protein (\%) & $58.66 \pm 0.01^{\mathrm{f}}$ & $61.18 \pm 0.02^{\mathrm{e}}$ & $61.99 \pm 0.02^{\mathrm{d}}$ & $64.08 \pm 0.03^{\mathrm{b}}$ & $65.14 \pm 0.03^{\mathrm{a}}$ & $63.90 \pm 0.06^{\mathrm{c}}$ \\
Crude Fat (\%) & $11.21 \pm 0.01^{\mathrm{f}}$ & $21.51 \pm 0.02^{\mathrm{a}}$ & $20.08 \pm 0.01^{\mathrm{b}}$ & $19.55 \pm 0.03^{\mathrm{c}}$ & $15.49 \pm 0.01^{\mathrm{d}}$ & $15.30 \pm 0.01^{\mathrm{e}}$ \\
Ash Content (\%) & $10.21 \pm 0.01^{\mathrm{f}}$ & $13.19 \pm 0.01^{\mathrm{e}}$ & $13.81 \pm 0.01^{\mathrm{c}}$ & $13.31 \pm 0.01^{\mathrm{d}}$ & $14.37 \pm 0.20^{\mathrm{b}}$ & $16.29 \pm 0.07^{\mathrm{a}}$ \\
\hline \hline
\end{tabular}

*Means in the same row with the same superscript are not significantly different from each other.

The physico-chemical parameter (Table 4) of water for the feeding period indicated slight changes in ranges of temperature, $\mathrm{P}^{\mathrm{H}}$, dissolved oxygen, ammonia, nitrate and nitrite values which were not significantly different from initial water quality parameters.

Table 5: Biweekly water quality parameters of fish tank fed MSKM.

\begin{tabular}{llllllll}
\hline \hline & Initial & Week 2 & Week 4 & Week 6 & Week 8 & Week 10 & Week 12 \\
\hline DO $(\mathrm{mg} / \mathrm{L})$ & $4.25 \pm 0.10$ & $5.79 \pm 0.39$ & $5.50 \pm 0.34$ & $5.08 \pm 0.15$ & $4.88 \pm 0.10$ & $5.19 \pm 0.07$ & $5.30 \pm 0.08$ \\
$\mathrm{pH}$ & $7.42 \pm 0.20$ & $7.37 \pm 0.03$ & $7.29 \pm 0.02$ & $7.27 \pm 0.02$ & $7.25 \pm 0.01$ & $7.12 \pm 0.03$ & $7.11 \pm 0.02$ \\
Ammonia $(\mathrm{mg} / \mathrm{L})$ & $0.00 \pm 0.00$ & $1.00 \pm 0.00$ & $1.00 \pm 0.00$ & $1.00 \pm 0.00$ & $1.00 \pm 0.00$ & $1.00 \pm 0.00$ & $1.00 \pm 0.00$ \\
Nitrate $(\mathrm{mg} / \mathrm{L})$ & $0.00 \pm 0.00$ & $0.08 \pm 0.04$ & $0.11 \pm 0.05$ & $0.11 \pm 0.05$ & $0.11 \pm 0.05$ & $0.11 \pm 0.05$ & $0.11 \pm 0.05$ \\
Nitrite $(\mathrm{mg} / \mathrm{L})$ & $0.00 \pm 0.00$ & $0.08 \pm 0.04$ & $0.11 \pm 0.05$ & $0.11 \pm 0.05$ & $0.11 \pm 0.05$ & $0.11 \pm 0.05$ & $0.11 \pm 0.05$ \\
Temp. $\left({ }^{0} \mathrm{C}\right)$ & $27.03 \pm 0.06$ & $26.99 \pm 0.03$ & $26.73 \pm 0.11$ & $27.15 \pm 0.10$ & $27.67 \pm 0.13$ & $25.57 \pm 0.10$ & $24.45 \pm 0.25$ \\
\hline \hline
\end{tabular}

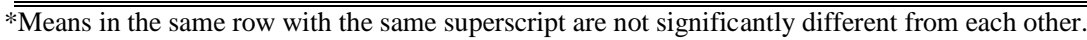

\section{DISCUSSION}

The nutritional content of fermented MSKM was within the range reported by Shittu et al., (2013) and Diarra (2014) but lower to Obasa et al., (2013). High-fat content of the fermented MSKM was similar to the range reported by Obasa et al., (2013) and Diarra (2014). While nitrogen-free extract in this study was lower in value than that of Shittu et al., (2013), Obasa et al., (2013), and Dakare et al., (2014). This variation resulted from species difference in the mango seed, processing methods employed, and high moisture content in the fermented MSKM for this study.

The experimental range of water quality parameters was within the acceptable ranges for catfish culture (Orisasona et al., 2016). The crude protein content of the experimental feed was within the recommended value for cultured C. gariepinus and this was in line with Faturoti et al., (2002) and Akegbejo-Samson et al., (2004). Lower crude fat in all dietary tratments of MSKM differs from observation reported by Obasa et al., (2013) and Sanogo (2018) for O. niloticus fingerlings and juveniles fed MSKM. 
The reduced response to feed has been asserted by Falaye and Oloruntuyi (1998) to be due to different carbohydrates contained in the energy by-products compared to maize. Also, Jansman (1993) reported tannin carbohydrate interaction to be better than its protein interaction. The performance of fish fed with T5 over T4 indicated the ability of $C$. gariepinus to digest high fiber content feed and this was also observed by Falaye et al., (2015) for fermented maize sievate.

Cost reduction and profitability concerning profit index, incidence cost, and net profit were highest at T3 (50\%) inclusion of MSKM and this is in line with Joseph and Abolaji (1997) on costeffectiveness of MSKM usage that can enhance farmers profitability. Cost of feed and value of feed reduction with an increased level of MSKM was similar to Orisasona et al., (2016). The body composition values of initial and final fish fed in this study were contrary to those reported by Falaye and Oloruntuyi (1998) as carcass protein increased in this study.

\section{CONCLUSION}

This study concludes that with the seasonal abundance of mango, the MSKM can adequately replace yellow maize in diets of $C$. gariepinus at $50 \%$ inclusion levels without affecting the fish performance and profit of fish farmers.

\section{REFERENCES}

Akegbejo-Samson, Y. (1999). The use of cassava flour as a substitute for yellow maize in diets for Clarias gariepinus fingerlings. Journal of Aquaculture in the Tropics, 247-253.

Akegbejo-Samson, Y., \& Olagunju, K. (2002). Growth response and nutrient digestibility of Clarias gariepinus fingerlings fed with varying levels of Parkia biglobosa slurry as energy source. Applied Fisheries and Aquaculture, 11(1), 1-6.

Akegbejo-Samson, Y., Oyewole, O.B., Olayinka, S.O., \& Olaniyan, T.O. (2004). Chemical composition and binding power of dried pulp wastes produced from the African locust bean (Parkia biglobosa) in low cost fish diets. Ife Journal of Science. 6(1), 30-34.

Association of Official Analytical Chemicals (AOAC) (2005). Official method of analysis of the AOAC (W. Horwitz editor eighteen edition, Washington; D.C.

Benitez, L.V. (1989). Amino Acid and fatty acid profiles in aquaculture nutrition studies. In S.S. De Silva (ed.) Fish Nutrition Research in Asia. Proceedings of the Third Asian Fish Nutrition Network Meeting. Asian Fish Society Special Publication. Asian Fisheries Society, Manila Philippines. 4, 166 p.

Bichi, A.H., \& Ahmadu, M.K. 2010. Growth performance and nutrient utilization of African Catfish (Clarias gariepinus) fed varying dietary levels of processed cassava leaves. Bayero Journal of Pure and Applied Sciences. 3(1), 118-122.

Dakare, M.A., Ameh, D.A., Agbaji, A.S., \& Atawodi, S.E. (2014). Chemical composition and antinutrient contents of yellow maize, raw and processed composite mango (Mangifera indica) seed kernel from Zaria, Kaduna State Nigeria. International Journal of Advanced Research. 2(7), 90-97.

Diarra, S.S. (2014). Potential of mango (Mangifera indica L.) seed kernel as a feed ingredient for poultry: a review. World's Poultry Science. 70(4), 279-288.

Fagbenro, O. (1996). Apparent digestibility of crude protein and gross energy in some plant and animal Clarias gariepinus (Siluri formers): Clariidae) (Sydenham 1980). Journal of Applied Ichthyology, 12, 67-68.

Falaye, A.E. (1992). Utilization of agro-industrial waste as fish feed stuffs in Nigeria. In: A.A., Eyo, A.M. Balogun (Eds.). Proceedings of the annual conference of Fisheries Society of Nigeria, Abeokuta $16^{\text {th }}-20^{\text {th }}$ Nov. 1992. pp: 47-57.

Falaye, A.E. (1998). Effect of maize brain diets on the growth and nutrient utilization of Tilapia (Orechromis niloticus). Nigeria Association for Aquaculture Sciences, 105-113.

Falaye, A.E., Adepoju, J.A., \& Ologhobo, A.I. (1999). The effect of cassava leaf meal on the growth performance of African catfish (Clarias gariepinus). Tropical Journal Animal Science, 1(2),73-78.

Falaye, A.E., \& Jauncey, K. (1999). Acceptability and digestability by tilapia (O. niloticus) of containing cocoa husk. Aquaculture Nutrition, 5, 157-161.

Falaye, A.E., \& Oluruntuyi, O.O. (1998). Nutritive potential of plaintain peel meal and replacement value for maize in diets of African catfish (Clarias gariepinus) fingerlings. Tropical Agriculture (Trinidad), 75(4), 488-492.

Falaye, A.E., Omoike, A., \& Adesina, S.B. (2015). Growth performance and nutrient utilization of catfish Clarias gariepinus fed varying inclusion level of fermented unsieved yellow maize. Continental Journal of Biological Sciences, 8(1), 14-23. 
Faturoti, E.O., Balogun, A.M., \& Ugwu, L.L.C. (2002). Nutrient utilization and growth responses of Clarias (Clarias lazera) fed different dietary protein levels. Nigeria Journal of Applied Fisheries and Hydrobiology, 1, 41-45.

Jansman, A.J.M. (1993). Tannins in feedstuffs for simple stomached animals. Nutrition Research Reviews, 6, 209-236

Jimoh, W.A., Ajasin, F.O., Adebayo, M.D., Banjo, O.T., Rifhat, A.O., \& Olawepo, K.D. (2013). Haematological changes in the blood of Clarias gariepinus fed Chrysophyllum albidum seedmeal replacing maize. Proceedings of $28^{\text {th }}$ FISON Annual Conference 2013. pp: 362-365.

Joseph, J.K., \& Abolaji, J. (1997). Effects of replacing maize with graded levels of cooked Nigerian mango-seed kernels (Mangifera indica) on the performance, carcass yield and meat quality of broiler chickens. Bioresource Technology, 61, 99-102.

National Research Council (N.R.C.) (1993). Nutrient requirement of fish. National Research Council, National Academy Press, Washington D.C. pp 114.

Obasa, O.S., Alatise, S.P., Omoniyi, I.T., Alegbeleye, W.O., \& George, F.A. (2013). Evaluation of fermented Mango (Mangifera indica) seed meal in the practical diet of Nile Tilapia, Oreochromis niloticus fingerlings. Croatian Journal of Fisheries, 71, 116-123.

Omojowo, T.M., Omojowo, F.S., \& Alatise, P.S. (2010). Growth response and nutritional evaluation of Mango peel-based diets on Tilapia (Oreochromis niloticus) Fingerlings. Researcher, 2(6), 44-49.

Omoregie, E. (2001). Utilization and nutrient digestibility of mango seeds and palm kernel meal by juvenile Labeo senegalensis (Antheriniformes: Cyprinidae). Aquaculture Research, 32, 681-687.

Orisasona, O., Falaye, A.E., Ajani, E.K., \& Kareem, O.K. (2016). Effect of replacement of soyabean with lima bean (Phaseolus lunatus) meal on growth and hematological parameters of Clarias gariepinus juveniles (Burchell, 1822). Journal of Aquatic Sciences, 31(2A), 229-240.

Pauzenga, U (1985). Feeding parent stock. Zootech. International, 22-24.

Sanogo, S. (2018). Performance of Oreochromis niloticus Juveniles Fed with Mango Seed formulated fish diet at different inclusion level. MSc. Dissertation, Department of Aquaculture and Fisheries Management, University of Ibadan.

Shittu, M.D., Olabanji, R.O., Ojebiyi, O.O., Amao, O.A., \& Ademola, S.G. (2013). Nutritional evaluation of processed Mango (Mangifera indica - Kent) seed kernel meal as replacement for Maize in the diet of growing crossbred Rabbits. Online Journal of Animal and Feed Research, 3(5), 210-215.

Sotolu, A.O., \& Byanyiko, S.Y. (2010). Nutritive Potentials of Parkia biglobosa pulp meal in partial replacement for maize in the diets of African Catfish (Clarias gariepinus) Juveniles. Journal of Environmental, Agricultural and Food Chemistry, 9(7), 1196-1202. 